\title{
大学生に和吅る性の発達と依存対象について
}

\author{
東京都立大学 \\ 清 水 弘 司 ${ }^{1}$
}

\section{A STUDY ON THE SEXUAL DEVELOPMENT AND TARGETS กF DEPENDENCE IN COLLEGE STUDENTS}

\section{HIROSHI SHIMIZU}

\author{
Tokyo Metropolitan University
}

\begin{abstract}
The correspondence between sexual development (S-D) and targets of dependence in college students was examined. Two questionnaires were used to investigate their sexual attitudes, sexual development, and central targets of dependence. Main results were as follows: (a) Subjects higher in S-D were more open to such sexual matters as virginity; (b) the higher subjects were in S-D, the more likely they were to select their lovers as a central target of their dependence; and (c) there was a tendency, although not statistically significant, suggesting that the lower subjects were in S-D, the more likely they were to select their family and best friends as the target.
\end{abstract}

性の発達は, 臨床的な方法と調査的な方法によって研 究されてきた. 臨床的方法による研究は, Freud (1905) 以後, 自我と対人関係の発達とのかかわりの中で性の発 達を検討している. Freud（1936）は “思春期になって, 衝動が強大になるにつれ，青年がぞんな防衛法をとる にしても，その結果はいつる対人関係にあらわれること はいらまでもない”とし, 性の発達と対人関係との関連 を指摘している。 また, Sullivan (1953) は，異性との 親密な関係を筑くためには，それ以前に同性同年輩者と の親密さをもつことが重要であるとし, 対人関係の発達 の方向を示している.このような臨床的な方法により共 通泊摘されることは, 性の発達比抢汀る対人関係の重 要性である。すなわち, 動物のような本能衝動的規範 （norm）をもたない人間の性は, 自ら後天的にそのため の対人関係を獲得しなければならないがゆ光に, 幼児期 からの対人関係によって影響を受けるものであることを 示唆している.

調查的方法に上る研究は, Kinsey, Pomeroy, \& Mar$\operatorname{tin}(1948)$ 以後, 多くの実態調査がなされ, 性の発達と性 格や環境条件等との関連について主に検討している。こ れらの中で，その調查の中心的テーマではないが，家庭 環境との関連に言及している研究もある.イギリスの 15

\footnotetext{
1 本研究をご指導下さった東京都立大学の詫摩武俊教 授，貴重なご示唆・資料をいただいた横浜国立大学の間 宮 武教授 - 依田 明教授, 千葉大学の青木孝悦助教 授，国立音楽大学の高橋恵子助教授に厚く感謝いたしま 9.
}

歳から 19 歳の青年を対象に調查した Schofield（1968） は，父親と仲のよい女子は性経験が少ない，母親と仲の よいものは男子・女子とも性経験が少ないことを見出し ている。また, わが国の 16 歳から 21 歳の高校生・大学 生を対象に調查した間宮（1976）は，生育家庭の暗くて 楽しくないふんい気の影響は性意識てついては男子・女 子ともないが，性的体験は暗くて楽しくない家庭に育っ た女子に多いことを見出している，これらの結果は，家 庭環境が青年の性経験に影響を及ぼすこと，家族との関 係が重要であることを示している. Harlow \& Harlow (1962) 芯行なった観察によると, 幼少期に隔離飼育さ れた赤毛ザルは成熟しても正常な性関係を発展させるこ とができなかった：母親や仲間との関係をるたずに成長 した赤毛ザルは性行動に障害があるといら結果が，人間 についても妥当するとするならば, 依存欲求の満足の如 何が性本能の発現を左右することを示唆しているように 思われる（土居, 1970）。

これらの研究に括いて, 性の発達と対人関係の関連が 明らかにされている。しかしながら，臨床的方法による ものは, 異常な (abnorma1) 対象についての治療・観 察過程から見出されたものであり, 一般的な発達之は異 なる面をるつことが考光られるために，一般的な対象に ついて検討することが必要であると思われる。また，調 查的方法によるものは, 家族との関係についての及言及 しているが，性の発達と関連する対人関係を考光るなら ば，異性をはじめとしてもっと広い対人関係について検 討する必要がある.さらに, 比較行動学の観察の示崚す 
る性欲求と依存欲求の結びつきを考慮するならば，対人 関係といっても, 依存要求を向ける対象について検討す ることが有効であると考兄られよう。

以上のことから, 本研究では一般の大学生を対象に, 性の発達と対人関係との対応関係を依存要求を向ける対 象について検討することを目的としている．ところで， 現在まで性の発達を記述する適切な基準は設定されてい ないので，どのように性の発達をとらえるかが問題と なる，そこで，性意識と性行動之の関連から性の発達の 測度を調查I飞祘いて検討し，それ之依存対象との対応 関係を調查正に标いて検討する。

\section{調 查 I}

総理府（1971，1975）が行なった調查によるとわが 国の青少年の性意識と性行動のあいだに微妙なずれが見 出されている。また, Eysenck (1976) は, 性格のタイ プ（精神病質・外向性・神経質）に上り性的態度（性的 過敏性等の 14 因子）が異なることを明らかにし，個人 差をとら光ることが必要であることを指摘している．個 人に打ける性の発達は意識之行動の両面に現わ机る。身 体的成熟が性についての意識を変光，その意識が性行動 に作用し，その行動がまた意識にフィード・バックする といらよらに相互関連するものと考兄られる。そこで本 調査では, 性の発達の程度を記述する測度について検討 するために，性的態度・性意識・性行動の関連をみた。

\section{方 法}

性的態度 Eysenck (1970) の98 項目からなる性的態 度についての質問を，わが国で行なったところ 7 因子が 抽出された，その因子に相応する質問項目から，わが国 で調査するのに不適切なもの（ピル等について）を除 き，20 項目を選んで調査項目とした。

性意識・性行動 Schofield (1968) は, 青少年の性行 動が発展する5段階を導き出している。また，田中 （1973）は，婚前の性行為のタイプを9段階を用いて調 查している.この両段階を答えやすく改訂し, 性行為の 内容が次第に発展するように, 次の 6 段階を構成した.

1. クラブ・趣味などのグループで行動をともにす る.

2. 二人でデートする.

3. 手を握ったり，腕を組んだりする.

4. キスしたり，抱きあったりする.

5. ペッティングする.

6. 性交する.

この段階を，異性との交際に抒いて許容できると考光 る限度について質問し, 性意識の指標とした。他方, こ れまでにどのような性的交渉をもったか，その体験をこ の段階について質問し, 性行動の指標とした.

実施調查対象は東京都内の 2 大学の 18 歳から 23 歳
の学生, 男性 216 名・女性 271 名で，いずれも無記名て 協力を依頼した。

結果の信頼性 調查対象の約 10\% に性体験について, $1 \cdot 2$ 週間沶いて再調查した. 一致率は 90.7 であった。

\section{結果と考察}

本調査でとらえた性的態度の構成について検討するた めに, 主因子法・バリマックス回転を行なったところ, Table 1 亿示すように 3 因子が抽出された。第 1 因子 は, 自分の性的欲求・性的関心についての受けとめ方や 敏感さなどを示す側面で，「性的感受性の因子〕とでも いらのが適当かと思われる，第 2 因子は，婚前交渉・性 話やわいせつ物等に対する態度を示す側面で，「性的道 德性の因子〕とでもいらのが適当かと思われる．第 3 因 子は, 異性と接している時の感じ方や気楽さなどを示す 側面で，〔対異性態度の因子〕とでもいらのが適当かと 思われる，本調査ではこれらの 3 因子が性的態度を構成 していたが，Eysenck (1976) のものでは14の因子で構 成されて和り，このほかの側面があることは十分考兄ら れる．これは質問項目の減少にともならものであろう．

性意識と性的態度の関連を検討するために, 異性との 交際に䍩いて許容できると考光る限度の 6 段階について 性的態度の各因子の因子得点の平均を分散分析した。 そ の結果 Table 2 に示すように, 第 1 因子, 第 2 因子に有 意差があった. 寸なわち段階 5 ・ 6 に含まれる許容限度 の高い人は自分の性的欲求・性的関心敏感でわずらわ されていたが, 中程度（段階 $2 \cdot 3 \cdot 4$ ) の人にその傾向 はなかった（第 1 因子）。また，段階が高くなるに従っ て性的事象に対する態度は開放的になっていた（第 2 因 子).

性行動之性的態度の関連を検討するために，これまで にもった性的体験の 6 段階について性的態度の各因子の 因子得点の平均を分散分析した。 その結果 Table 3 に示 すように，第 2 因子，第 3 因子に有意差があった。すな わち性体験の段階が進んでいる人ほぞ性的事象に対する 態度は開放的になっていた（第 2 因子）。また，性体験 の段階が進んでいる人ほど異性と接する機会も多くて気 楽に交際していた（第 3 因子）.

性意識と性行動の関連を検討するために，異性との交 際に执いて許容できると考える限度の 6 段階とこれまで 飞もった性的体験の 6 段階を比較した。 その結果 Table 4 飞示すように, 男性・女性ともに性意識と性行動の市 いだにずれがあるものが多かった．このずれの方向から 分類すると, 性意識より性行動が先行している行動先行 型, 性意識と性行動が一致している一致型, 性行動より 性意識の先行している意識先行型に分けることができ る. 各々の型の比率は, 男性では行動先行型 $9.1 \%$, 一 致型 $26.8 \%$, 意識先行型 $64.1 \%$ であった. 女性では行 動先行型 $19.2 \%$, 一致型 $27.8 \%$, 意識先行型 $53.0 \%$ で 
TABLE 1

Sexual attitudes

\begin{tabular}{|c|c|c|c|}
\hline & \multicolumn{3}{|c|}{ Rotated factor matrix } \\
\hline & Factor 1 & Factor 2 & Factor 3 \\
\hline 1. I have many friends of the opposite sex. & -.065 & .074 & .633 \\
\hline 2. I feel at ease with people of the opposite sex. & .119 & .024 & .753 \\
\hline 3. I am embarrassed to talk about sex. & .060 & -.553 & -.099 \\
\hline 4. Sex jokes disgust me. & -.066 & -.559 & -.015 \\
\hline 5. I have had more than one lover at the same time. & .122 & -.004 & .512 \\
\hline 6. I feel at ease with people of my own sex. & .056 & -.110 & -.472 \\
\hline 7. I don't feel nervous with the opposite sex. & -.002 & -.015 & .757 \\
\hline 8. I consciously try to keep sex thoughts out of my mind. & .003 & -.532 & .057 \\
\hline $\begin{array}{l}\text { 9. If you were offered a highly pornographic book, would you } \\
\text { accept? }\end{array}$ & .280 & .610 & .098 \\
\hline 10. If you were invited to see a "blue" film, would you accept? & .292 & .588 & .128 \\
\hline 11. All in all I am satisfied with my sex life. & -.470 & -.205 & .116 \\
\hline 12. Masturbation is unhealthy. & .130 & -.452 & .044 \\
\hline 13. Sexual feelings are sometimes unpleasant to me. & .583 & -.195 & .020 \\
\hline 14. It is better not to have sex relations until you are married. & -.042 & -.651 & -.064 \\
\hline 15. Sometimes thinking about sex makes me very nervous. & .757 & -.096 & .044 \\
\hline 16. Sex without love is highly impure. & -.167 & -.533 & -.038 \\
\hline 17. Virginity is a girl's valuable possession. & $.044^{\circ}$ & -.541 & -.059 \\
\hline 18. Virginity is a boy's valuable possession. & .135 & -.533 & -.021 \\
\hline 19. Toughts about sex disturb me more than they should. & .683 & .014 & .048 \\
\hline 20. Sometimes sexual feelings overpower me. & .641 & .191 & .102 \\
\hline
\end{tabular}

TABLE 2

Analyses of variance using mean factor scores of sexual attitudes in each stage of sexual consciousness

\begin{tabular}{c|ccc}
\hline \multirow{2}{*}{ Stage } & \multicolumn{3}{|c}{ Factor } \\
\cline { 2 - 4 } & \multicolumn{1}{|c}{1} & 2 & 3 \\
\hline 1 & .043 & -.478 & -.064 \\
3 & -.115 & -.343 & -.069 \\
4 & -.074 & -.288 & -.007 \\
5 & -.067 & -.035 & -.038 \\
6 & .418 & .271 & .387 \\
\hline$d f$ & .269 & .996 & .037 \\
\hline$F$ & $2.546^{*}$ & $22.982^{* *}$ & .979 \\
$* 0.05$ & $* * p<.01$ & & 5 \\
\hline
\end{tabular}

TABLE 3

Analyses of variance using mean factor scores of sexual attitudes in each stage of sexual behaviour

\begin{tabular}{c|ccc}
\hline \multirow{2}{*}{ Stage } & \multicolumn{3}{|c}{ Factor } \\
\cline { 2 - 4 } & 1 & 2 & 3 \\
\hline 1 & .067 & -.311 & -.483 \\
2 & -.163 & -.163 & -.262 \\
3 & -.148 & .142 & .201 \\
5 & -.093 & .189 & .376 \\
6 & .305 & .281 & .536 \\
\hline$d f$ & .181 & .745 & .800 \\
\hline$F$ & 5 & 5 & 5 \\
\hline$* * 01$ & 2.159 & $9.841^{* *}$ & $18.909^{* *}$ \\
\hline
\end{tabular}


TABLE 4

Association between the stages of sexual consciousness and sexual behaviour

\begin{tabular}{|c|c|c|c|c|c|c|c|c|c|c|c|c|c|c|}
\hline \multirow{3}{*}{$\begin{array}{l}\text { Stage } \\
\begin{array}{l}\text { Sexual } \\
\text { consci- } \\
\text { ousness }\end{array}\end{array}$} & \multicolumn{14}{|c|}{ Sexual behaviour } \\
\hline & \multicolumn{7}{|c|}{ Male } & \multicolumn{7}{|c|}{ Female } \\
\hline & 1 & 2 & 3 & 4 & 5 & 6 & Total & 1 & 2 & 3 & 4 & 5 & 6 & Total \\
\hline 1 & 4 & & & & & & 4 & 5 & & 3 & 3 & & & 11 \\
\hline 2 & 13 & 7 & 5 & 1 & 1 & 2 & 29 & 9 & 17 & 12 & 3 & 2 & 3 & 46 \\
\hline 3 & 15 & 6 & 17 & 1 & 2 & 3 & 44 & 22 & 24 & 21 & 8 & 2 & 5 & 82 \\
\hline 4 & 22 & 13 & 15 & 8 & 1 & 2 & 61 & 20 & 22 & 26 & 24 & 5 & 5 & 102 \\
\hline 5 & 1 & 3 & 2 & 4 & 5 & 1 & 16 & 1 & 1 & 4 & 2 & 5 & & 13 \\
\hline 6 & 13 & 5 & 8 & 8 & 6 & 15 & 55 & & 2 & 3 & 4 & 1 & 2 & 12 \\
\hline Total & 68 & 34 & 47 & 22 & 15 & 23 & 209 & 57 & 66 & 69. & 44 & 15 & 15 & 266 \\
\hline
\end{tabular}

めった. 男性・女性とも行動先行型より意識先行型の占 める比率が高く, 性行動より性意識が先行する傾向にあ るが，男性においてその傾向が著しい。この意識先行の 傾向は，意識的には許容していても，それを行動的に実 行する対人関係をもたないことによるであろう。あるい は対人関係はもっていても，実際の行動にらつすことを ためらっているためかもしれない。意識先行・行動先行 といら 2 万向のずれの様式については, 環境要因等を加 觉て検討されることが必要であろう。

性的態度・性意識・性行動からとらえた性の発達に は, 同一世代の大学生でも個人差や性差があった。ささら に, 個々の青年の性でもその意識と行動のあいだにずれ が見出された.このことから, 個人の性の発達の程度を 性意識・性行動のどちらか一方だけで記述することは不 適切であると考えられる.さらに，本調査で用いた性意 識・性行動の 6 段階の一致しているものは男性・女性と も $27 \%$ 前後と低いことから, 発達の段階の基準をゆる めることが必要であるう。

\section{調 査 II}

間宮（1976）は，環境条件が性意識・性行動に及ぼす 影響を検討し, 次のような結果を得た。 “異性接触欲, 異性接触経験, 異性ハント, キッス経験, ペッティング 経験, 性交経験などの性意識・性行動体験では, 女子は 家庭のふんい気如何亡有意の関連をもら, 家庭が暗く て楽しくないふんい気の下に生活しているもののほう が，そのような体験が多い傾向にある.”また，男子の 性交経験は両親健在のものに少なく, 一方を失なってい るものに多く, 両親とも失なっているものに最も多かっ $r^{2}$.

Schofield (1968) の研究に和いても，親と仲のよいも のは性経験が少なかった。なた，性経験をもつものは， 男子・女子とも性以外の問題でも両親に相談することが
少なかったこれらの結果は，性体験の少ないものが多 いものより両親との結びつきが強いことを示唆してい る.すなわち, 性意識・性行動の発達していないもの は, 発達しているものより両親と親密な親子関係をもつ 傾向があることが予測できる、したがってこのことか ら，性の発達の程度により，親密な感情をもって接する 対象が異なることが考えられよう。

高橋（1973）は，女子青年に和ける依存性の発達につ いて検討し，次のような結果を得た。同性の友人は高校 生に扣いて最名依存の対象として重視されていた。これ に対して，中学生ではまだ重要な対象とはなっていなか った。そして，大学生になると同性の友人はさして重要 な対象とはなり得なかった。他方, 愛情の対象は年齢の 上昇につれて重要な対象となっていった，高橋による 之, 大学生ではかつて (高校生時代に) 友人が果たして いた機能までも，愛情の対象がよりょく果たすよらにな るからではないかと考兄られた。また，高校生の親友を 中心とする型は, 親友一愛情の対象両者を中心とする型 に近いと又なされ，愛情の対象への移行型と考光られ た.すなわち，依存対象は同性の友人から愛情の対象へ 変化することが多く, 年齢の上昇につれて性的な面が顕 著になってくることを示しているといえよう.さらに, 生活史による調查 (高橋, 1976) から, 大学生で現在家族 が優位になった対人行動の枠組をもっているものは幼児 期からその傾向がみられた。 それに対して, 現在非家族 が優位な対人行動の枠組をもっているものは幼児期から 明るい積極的な子ぞもで，同性だけでなく異性の友人と の交渉が活発であったことを報告している。この結果か ら，依存性の発達に家族を中心とするものと, 非家族を 中心とするものがあることが考光られよう，そして，先 の間宮や Schofield の結果にみられるように，両親との 関係により性体験が異なることを考慮するならば，依存 要求を向ける対象により, 同一世代の青年でも性の発達 
TABLE 5

Association between sexual development and the focus of dependence

\begin{tabular}{|c|c|c|c|c|c|c|c|c|}
\hline \multirow{3}{*}{ Focus of dependence } & \multicolumn{8}{|c|}{ Group of sexual development } \\
\hline & \multicolumn{4}{|c|}{ Male } & \multicolumn{4}{|c|}{ Female } \\
\hline & Low & Middle & High & Total & Low & Middle & High & Total \\
\hline Lover & $\begin{array}{c}6 \\
(25.0)\end{array}$ & $\begin{array}{l}21 \\
(51.2)\end{array}$ & $\begin{array}{c}14 \\
(51.9)\end{array}$ & $\begin{array}{l}41 \\
(44.6)\end{array}$ & $\begin{array}{c}8 \\
(25.8)\end{array}$ & $\begin{array}{l}40 \\
(50.6)\end{array}$ & $\begin{array}{c}5 \\
(62.5)\end{array}$ & $\begin{array}{c}53 \\
(44.9)\end{array}$ \\
\hline Best friend & $\begin{array}{c}7 \\
(29.2)\end{array}$ & $\begin{array}{c}8 \\
(19.5)\end{array}$ & $\begin{array}{c}4 \\
(14.8)\end{array}$ & $\begin{array}{l}19 \\
(20.7)\end{array}$ & $\begin{array}{c}9 \\
(29.0)\end{array}$ & $\begin{array}{l}17 \\
(21.5)\end{array}$ & $\begin{array}{c}1 \\
(12.5)\end{array}$ & $\begin{array}{c}27 \\
(22.9)\end{array}$ \\
\hline Respected person & $\begin{array}{c}4 \\
(16.7)\end{array}$ & $\begin{array}{c}4 \\
(9.8)\end{array}$ & $\stackrel{2}{(7.4)}$ & $\begin{array}{c}10 \\
(10.7)\end{array}$ & $\begin{array}{c}7 \\
(22.6)\end{array}$ & $\begin{array}{l}6 \\
(7.6)\end{array}$ & $\begin{array}{c}1 \\
(12.5)\end{array}$ & $\begin{array}{l}14 \\
(11.9)\end{array}$ \\
\hline Brother/Sister & $\frac{1}{(4.2)}$ & $\begin{array}{l}2 \\
(4.9)\end{array}$ & $\stackrel{3}{(11.1)}$ & $\stackrel{6}{(6.5)}$ & $\begin{array}{l}2 \\
(6.5)\end{array}$ & $\stackrel{3}{(3.8)}$ & $\begin{array}{c}1 \\
(12.5)\end{array}$ & $\begin{array}{l}6 \\
(5.1)\end{array}$ \\
\hline Mother & $\stackrel{3}{(12.5)}$ & & $\stackrel{2}{(7.4)}$ & $\begin{array}{c}5 \\
(5.4)\end{array}$ & $(3.2)$ & $\begin{array}{c}5 \\
(6.3)\end{array}$ & & $\begin{array}{l}6 \\
(5.1)\end{array}$ \\
\hline Teacher & & $\begin{array}{l}2 \\
(4.9)\end{array}$ & & $\stackrel{2}{(2.2)}$ & & $\begin{array}{l}3 \\
(3.8)\end{array}$ & & $\stackrel{3}{(2.5)}$ \\
\hline Father & $\stackrel{1}{(4.2)}$ & & & $\stackrel{1}{(1.1)}$ & & $\stackrel{2}{(2.5)}$ & & $\stackrel{2}{(1.7)}$ \\
\hline Plural focus & $\stackrel{2}{(8.3)}$ & $\begin{array}{c}4 \\
(9.8)\end{array}$ & $\left(\begin{array}{l}2 \\
(7.4)\end{array}\right.$ & $\stackrel{8}{(8.8)}$ & $\begin{array}{c}4 \\
(12.9)\end{array}$ & $\begin{array}{l}3 \\
(3.8)\end{array}$ & & $\stackrel{7}{(5.9)}$ \\
\hline Total & $\begin{array}{c}24 \\
(100.0)\end{array}$ & $\begin{array}{c}41 \\
(100.0)\end{array}$ & $\begin{array}{c}27 \\
(100.0)\end{array}$ & $\begin{array}{c}92 \\
(100.0)\end{array}$ & $\begin{array}{c}31 \\
(100.0)\end{array}$ & $\begin{array}{c}79 \\
(100.0)\end{array}$ & $\begin{array}{c}8 \\
(100.0)\end{array}$ & $\begin{array}{l}118 \\
(100.0)\end{array}$ \\
\hline
\end{tabular}

の程度に相違があることが予測できる。

ところで, 調查Iの結果にみられるように, 個人の性 でもその意識と行動のあいだにずれがあり，ぞちらか一 方だけで性の発達の程度を決定することは適当でないと 考觉ら机る。そこで本調查では, 性意識・性行動の両面 からとら元たるのを“性の発達”とした，そ饥之依存対 象之の対応関係を検討するために，以下の予測が立てら れた。

（1）性の発達しているるのは，その発達していない ものより, 愛情の対象を依存要求を向惊る中核的な対象 （以下依存の焦点と呼ぶ）とする率が高いであうう。

（2）性の発達していないものは, 矢の発達している ものより，両親を依存の焦点とする率が高いであるう。

\section{方 法}

性の発達＼cjkstart調査Ｉ と同じ性意識・性行動の 6 段階の指 標を用いたが，調査工の結果にみられた両者のずれを考 慮し, 次の低・中・高の 3 群に分類した。すなわち, 性 意識・性行動ともに 1 - 2 段階にあるものを低位群, $3 \cdot 4$ 段階にあるるのを中位群，5・6 段階市るるのを 高位群とした（調査 I の方法参照）.

依存対象 高橋（1973）は，依存を(1)さまざまな対 象に対して，(2) どのよらな接触や反応を，(3) ぞれほ ぞ強く求めているか，によってとら六た，本調査でも， 対象・様式・強度の 3 要因によって依存対象をとら光
た. 具体的には高橋 (1968) の質問項目を簡略化して, 36 項目の中 15 項目を選んだ. 項目の選択飞あたっては 6 人の心理学専攻の大学院生に依頼して Q 分類を行な い, 4 人が一致した項目を採用した ${ }^{2}$. この 15 項目は （1）ともにあることを求める・(2）注意をむけてむらう ことを求める・(3) 助力を求める・(4) 保証を求める・ （5）心の支光を求めるの 5 様式からなり, 各々 3 項目に よって示された。この 15 項目に関して，母親・父親・ 最も親しいきょうだいの一人・最も親しい友人（以下親 友と呼ぶ)・異性の友人で一番好きな人（以下愛情の対 象之呼ぶ)・最も尊敬している人・最も尊敬している先 生の計 7 人について, 気持らにあてはまる程度を[そう である]から〔ちがう〕の 5 段階で独立に, 都合 7 回評 定させた.この 5 段階に 4 から 0 の得点をあた劣を, 各対 象について依存の得点を 15 項目の合計であらわした。 この得点の最高のものを, 依存対象の焦点とした. 同最 高得点の場合は複数焦点として, 結果の分析から除い た.

実施 調查対象は調查Iに同じである。性意識・性行 2 調査結果をクラスター分析したところ，1 項目に様 式のずれがあった．他の 14 項目は Q 分類の結果と同一 のをとまりを示した。焦点の決定には影響がないので， そのま用いている。 また, 焦点の決定の仕方は, 上述 するように高橋（1968）の方法とは異なっている. 
動が前記の低・中・高の 3 群分類のいずれかに分類され たものは, 男性 92 名・女性 118 名であった (Table 4 参 照).

\section{結果と考察}

性の発達の 3 群分類の構成は, 男性が低位群 24 名・ 中位群 41 名・高位群 27 名, 女性が低位群 31 名・中位 群 79 名・高位群 8 名であった．各群に执いて依存対象 の焦点とされた対象の占める比率が Table 5 に示されて いる. 本調査の対象である大学生の依存対象の一般的傾 向を検討するために，どの対象が焦点とされる率が高い かをみた. 男性の $44.6 \%$ ・女性の $44.9 \%$ が愛情の対象 を焦点としていて，他の対象が焦点とされる率よりかな り高かった。この結果は, 高橋（1973）の大学生の単独 焦点型では愛情の対象とするものが最も多いという結果 と一致している。これは大学生では性の発達が顕著にな ってきたために，異性に対して親密な感情を向けるもの が多くなっていることを示していると考えられる.

性の発達の程度と依存の焦点として愛情の対象が選ば れる傾向について検討するために, 性の発達の 3 群分類 の各群において愛情の対象の占める比率の Bartholomew ・傾向検定を行なった. 男性 $\left(\bar{\chi}_{3}{ }^{2}=5.10,-\rho_{12}=\right.$ $0.4, p<.5) \cdot$ 女性 $\left(\bar{\chi}_{3}{ }^{2}=6.56,-\rho_{12}=0.2, p<.25\right)$ とも有意な傾向があった。 すなわち, 性の発達の程度が 高いものほど愛情の対象を依存の焦点とする傾向があっ た.ことに女性では, Fig. 1 に示すよらに, 一次的 (linear) な関係にあるといえよう。これらの結果は，性 の発達と愛情の対象との対応関係を期待した予測 (1) を 支持しているといえよう。これは性の発達しているもの は, その人の生活の中で異性との関係が重要な位置を占 めているためと考觉られる.

性の発達の程度が低いものほど両親を依存の焦点とす る傾向について検討したが，はっきりした結果は得られ なかった。これは各群とも母親・父親を焦点とするもの が, 高橋 (1973) の結果に較べてもさわめて少なく, こ
の傾向を検討するのに不適切であったためであろう．こ の結果は, 性の発達と両親との対応関係を期待した予測 （2）を支持していない。この予測については，年紫の幅 を大さくして再検討されることが必要であろう. 次いで このことに関連して，家庭のらんい気が女子の性体験に 影響を及ぼすといら間宮（1976）の結果から，家族との 関係を検討した. 性の発達の 3 群分類の各群において, 家族の一員である母親・父親・きょらだいのいずれかを 依存の焦点としたものの比率が Fig. 2 に示されている.

男性・女性とも有意な傾向はなかった。しかし，女性で は性の発達の程度が低いもの汪ど家族を依存の焦点とす る傾向を示唆するものがあり, 間宮（1976）の結果と類 似しているといえよう。

性の発達の程度と依存の焦点として親友が選ばれる傾 向について検討するために, 性の発達の 3 群分類の各群 に持いて親友の占める比率を傾向検定した. 男性・女性 とも有意な傾向はなかったが, Fig. 3 に示されるよう に，性の発達しているものほど親友を依存の焦点とする 比率は少なかった．したがって，この傾向を示唆するも のがあると考えられるが, 性の発達の程度の低いと予想 される高校生等を含め年齢の幅を大さくして再検討され ることが必要であろら。ところで, 性の発達の程度の低 いものでは男性の $29.2 \%$ ・女性の $29.0 \%$ が親友を依存 対象の焦点としていて，他の対象が焦点とされる率より 高かった. 高橋（1973）によれば, 同性の友人は高校生 に和いて最も依存の対象として重視されていた。これは 大学生でも性の発達していないものでは, 高校生の場合 と同じように，その人の生活の中で親友との関係を最も 重視しているものがかなりいることを示しているといえ よう.

本調査の対象である大学生では, 一般に愛情の対象が 依存の焦点とされる率が最も高かったが, 中でも性の発 達の程度が高いものほどその傾向が強かった。しかしな がら, 性の発達の程度の低いものでは同性の親友や家族

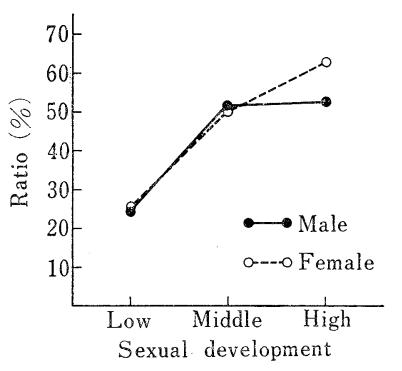

FIG. 1. Ratio of selecting a lover as a focus of dependence in each group of sexual development.

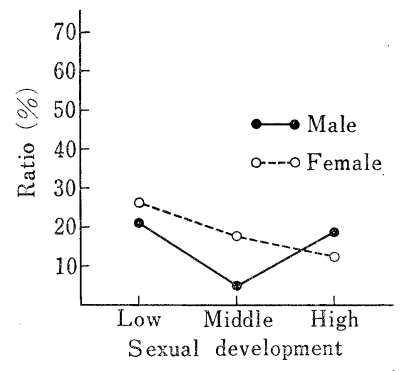

Fí. 2. Ratio of selecting a family member as a focus of dependence in each group of sexual development.

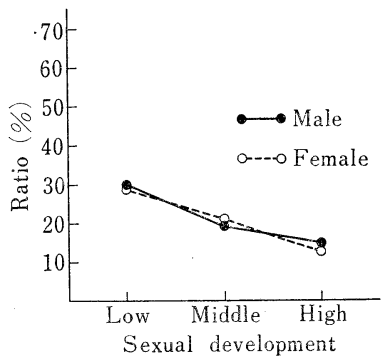

FIG. 3. Ratio of selecting a best friend as a focus of dependence in each group of sexual development. 
が依存の焦点とされる率が高かった。このことから，性 の発達の程度により依存要求を向ける対象に相違がある といえよう。すなわち, 性の発達の程度が高くなるにし たがって，対人関係も性的な要因を反映したものにな り，異性との関係が重要になっていくと考觉られる．そ れに対し, 性の発達の程度の低いものでは性的要因の影 響は少なく，親友や家族との関係が重要な位置を占めて いるものと思われる。ささらに，性の発達と依存要求を向 ける対象のあいだにはこのような一方向的な影響だけで なく, 対人関係の枿組の変化, たとえば愛情の対象があ らわれることにより, 性の発達の程度が高くなることも 考えられる。こらしたことから，大学生に和ける性の発 達と依存対象とは相互関連的に発達・変容していくと考 えられるのではないだろらか，本研究ではその対応関係 を検討するにとどまったが，両者の因果的な関係につい て, 同一対象についての縦断的研究やパス解析等の統計 的検討を加えることが必要であると考えられる，また， 発達的に年齢の幅を大きくして，第 2 次性徵の出現した 以降の中学生・高校生等を対象に実証的に検討すること が必要であろう.

\section{要約}

本研究の目的は, 大学生を対象に性意識と性行動の関 連からとらえた性の発達と対人関係との対応関係を依存 要求を向ける対象について検討することである.

調査 I の目的は性意識と性行動の関連から性の発達の 測度を検討することである。性的態度に関する質問と性 意識・性行動の発達の程度を示す 6 段階（グループで交 際するから性交まで）の指標が用いられた。

主な結果は次の通りである.

1. 性意識（異性交際に扣ける許容限度）の段階が高 い人汪ど，性的事象に対する態度は開放的になってい た. 性意識の段階の高い人は, 自分の性的欲求・性的関 心に敏感でわずらわされていた。

2. 性行動（性体験）の段階が高い人ほど，性的事象 に対する態度は開放的になり，異性と接する機会も多く て気楽に交際していた。

3. 男性・女性とも性行動より性意識が先行している 傾向があるが，男性に赫いて著しかった。また，性の発 達の程度は, 個人でもその意識と行動のあいだにずれの あるものが多かった。

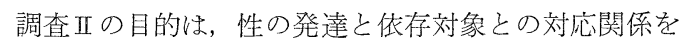
検討することである。性の発達は, 性意識・性行動をこ みにした低・中・高の3群を指標にした。依存対象は, 対象・様式・強度から依存の中心対象（焦点）を求为 た。

主な結果は次の通りである。

1. 一般に大学生では愛情の対象を依存の焦点とする
ものが多く，男性・女性とも約 $45 \%$ あった。

2. 性の発達の程度が高いもの注ど, 愛情の対象を依 存の焦点とする有意な傾向があった.

3. 性の発達の程度が低いものほど, 家族を依存の焦 点とする有意な傾向はみられなかった。 しかし，女性で はとれを示唆する傾向があった。

4. 性の発達の程度が低いるのほど, 親友を依存の焦 点とする有意な傾向はみられなかった。しかし，男性・ 女性ともとれを示唆する傾向があった。

\section{引用文 献}

土居健郎 1970 精神分析と精神病理 第 2 版 医学書 院

Eysenck, H. J. 1970 Personality and attitudes to sex : A factorial study. Personality, 1, 355-376.

Eysenck, H. J. 1976 Sex and personality. London : Open Books.

フロイト，A．外林大作(訳) 1958 自我と防衛 誠信 書房 (Freud, A. 1936 Das Ich und Abwehrmechanismen. Internationaler Psychoanalytischer Varlag.)

フロイト，S．㩓田克躬・吉村博次(訳) 1969 性欲論 三篇 フロイト著作集 第 5 巻 人文書院 (Freud, S. 1905 Drei abhandlungen zur Sexualtheories.)

Harlow, H.F., \& Harlow, M. K. 1962 Social deprivation in monkeys. Scientific American, 207, 136-146.

Kinsey, A. C., Pomeroy, W. B., \& Martin, C. E. 1948 Sexual behavior in the human male. Philadelphia: Saunders.

間宮 武 1976 わが国青年（学生・生徒）に和ける性 行動の性差に関する調査研究 横浜国立大学教育紀 要, 16, 14-48.

Schofield, M. 1968 The sexual behaviour of young people. London : Penguin Books.

総理府青少年対策本部 1971 青少年の性意識 大蔵省 印刷局

総理府青少年対策本部 1975 青少年の性行動 日本性 教育協会(編) 小学館

サリヴァン, H.S.中井久夫・山口 隆 (訳) 1976 現 代精神医学の概念 (Sullivan, H.S. 1953 Conceptions of modern psychiatry. New York: Norton)

高橋恵子 1968 女子青年に和忷る依存性の発達 依田 新(編) 現代青年の人格形成 金子珰房 Pp. 21-44.

高橋恵子 1973 女子青年に频け西依存の発達 児童心 理学の進歩, 12, 金子書房, 256-280.

高橋恵子 1976 親子関係と発達 岡本夏木・三宅和夫 (編) 心理学 5 発達 有斐閣 Pp. 85-102.

田中靖政 1973 日本の若者たちの性的後進性々今後の 課題 現代性教育研究, 5, 小学館, 32-39.

-1979. 5. 10. 受稿— 


\section{SUMMARY}

The purpose of the present study was to examine the correspondence between sexual development and targets of dependence in college students.

In Study I, the association between sexual consciousness (S-C) and sexual behaviour (S-B) was examined. A questionnaire was used to investigate their sexual attitudes and to evaluate their S-C and S-B in terms of six progressive stages ranging from socializing in mixed-sex groups to sexual intercourse.

The main results were as follows:

(1) Subjects higher in S-C, as defined by the permissible limit in relationship with the opposite sex, were more open to such sexual matters as virginity and sex-related talks. They, however, tended to be sensitive to and troubled by their own sexual desires and concerns (see Table 2).

(2) Subjects higher in S-B, as defined by actual sexual experiences, were more open to sexual matters and also enjoyed their relationship with the opposite sex (see Table 3).

(3) The comparison between S-C and S$B$ showed that S-C on average tended to be higher than S-B in both males and females. Correspondingly, a great number of subjects showed discrepancies between S-C and S-B (see
Table 4).

In Study II, the correspondence between sexual development (S-D) and targets of dependence was examined. The subjects were divided into low-, middle-, and high-S-D groups by combining their S-C and S-B scores. The central target (focus) was determined by three factors: Object, mode, strength.

The main results were as follows:

(1) About $45 \%$ of both males and females selected their lovers as a focus of their dependence. This ratio was much higher than any other targets (see Table 5).

(2) The higher subjects were in S-D, the more likely they were to select their lovers as a focus. This tendency was statistically significant (see Fig. 1).

(3) In females, there was a tendency, although not statistically significant, suggesting that the lower subjects were in $S-D$, the more likely they were to select their family members as a focus (see Fig. 2).

(4) Both males and females showed a tendency, while not statistically significant, suggesitng that the lower subjects were in S$\mathrm{D}$, the more likely they were to select their best friends as a focus (see Fig. 3). 